\title{
Joseph MitcheLL.
}

Joseph Mitchell, civil engineer, for long resident in Inverness, and latterly in London, was born at Forres on the 3rd November 1803. His father, John Mitchell, was appointed, under Mr Telford, as inspector of works, in connection with the extensive road works, which, with the other great works then being carried out by $\mathrm{Mr}$ Telford, were the first means of opening up the Highlands to full access with the southern parts of Great Britain. Mr John Mitchell held the general inspectorship of the extensive system of communication known as the Highland Roads and Bridges. It is worthy of remark that $\mathrm{Mr}$ John Mitchell attracted the attention not only of Mr Telford, but also of the poet Southey, who wrote in terms of high commendation, both of his talents and moral qualities.

Joseph Mitchell seems in many respects to have inherited his father's energy and abilities. He was educated at the celebrated Academy of Inverness, which for many years was under the charge of the well-known Alexander Nimmo, C.E., who was long the personal friend of Telford and of Sir David Brewster, for whose Encyclopcedia he wrote several articles.

Mr Mitchell became a Fellow of this Society in 1843. He became a civil engineer under the immediate auspices of Mr Telford, who caused him to engage in the practical masonry of the lockgates of the Caledonian Canal at Fort Augustus, after which Mr Mitchell not only became an apprentice in his office, but an inmate of his house, a striking proof of the high opinion which that great engineer had formed of his personal qualities. Here he made the first survey of the St Catherine Docks, which were carried out under Mr Telford's superintendence.

In 1824, when only twenty-one years of age, the whole of the Highland Roads and Bridges system was, on the death of his father, put under Mr Joseph Mitchell's charge, a fact which shows how great a trust was reposed in him by Mr Telford. During the long period of thirty-nine years he had these roads, extending over the rugged and difficult counties of Inverness, Ross, Cromarty, Sutherland, and Caithness, not only to inspect but to provide additional roads and 
bridges over the most difficult ravines and passes and the most formidable kind of rivers. There was in all this difficult country ample room for varied engineering practice, which was throughout of a most successful type. Besides all this Government work, he carried on an extensive private practice, involving the expenditure of about $£ 180,000$. He was also employed by Government to design and erect forty churches in outlying districts and lonely islands.

In 1828 he was appointed engineer to the Scottish Fishery Board, and designed and superintended the execution of very many useful harbours, as for example at Burnmouth, Coldingham, and Dunglass, in Berwickshire, at Buckhaven and Cellardyke on the Fife coast, as well as at various fishing stations on the coasts of Caithness and among the Hebrides. The large fishing harbour at Dunbar, which cost nearly $£ 40,000$, was also one of Mitchell's, as well as Lybster, on the Caithness coast, where, in order to avoid as much as possible conflict with the open sea, he preferred to recess the basin landwards of high water, instead of carrying the works outwards. $\mathrm{He}$ also designed improvements at Wick on the same principle. $\mathrm{Mr}$ Mitchell is well known as having been the engineer of the extensive work known as the Highland Railway between Perth and Inverness, as well as of most of the railways to the northward of Inverness. Mr Mitchell, in conjunction with Messrs William and Murdoch Paterson, was engineer for the Skye line.

Mr Mitchell has left behind him so many works of a varied, and some of them of a difficult nature, as to prove his natural sagacity and skill. He was always highly esteemed by his professional brethren for his geniality and high professional honour as well as his ability. True and genial as a friend, his death was felt by many as a personal loss, both in Scotland and in London, where he principally lived in later years. $\mathrm{He}$ died in London on 26th November 1883, at the advanced age of eighty years. 